\title{
Analysis of Problem of Perceiving and Understanding Literary Texts by Philology Students
}

\section{Аналіз проблеми сприймання й розуміння студентами-філологами творів художньої літератури}

\section{Inna Khyzhniak}

Dr. in Pedagogy, Associate Professor, Dean of Primary, Technological and

Vocational Education Faculty

\author{
Інна Хижняк \\ доктор педагогічних наук, доцент, \\ декан факультету початкової, \\ технологічної та професійної освіти
}

\section{Nazar Liashov}

Ph.D. in Philological,

Associate Professor

\section{Назар Ляшов}

кандидат філологічних наук, доцент

E-mail:nzr2012@ukr.net orcid.org/0000-0001-6176-5179

Donbas State Pedagogical University

19, Henerala Batiuka Str.,

Slovyansk, Donetsk Reg.,

Ukraine, 84116
ДВНЗ «Донбаський державний педагогічний університет»

$\triangle$ вул. Генерала Батюка, 19, Слов'янськ, Донецька обл.,

Україна, 84116

Original manuscript received December 04, 2018

Revised manuscript accepted September 27, 2019 


\section{ABSTRACT}

Introduction. The article discloses the importance of conducting psycholinguistic analysis of perceiving and understanding voluminous literary texts by philology students; the issue is relevant as there is a lack of research that concerns revealing the essential aspects of these processes, as well as the influence of conducting psycholinguistic analysis on effective performance in philology students' professional activities is highlighted. The goal of the article is to conduct a theoretical analysis of the problem of perceiving and understanding literary texts by philology students and identify the level of development of future teachers of language and literature individual practical skills on decoding the content of a large prose fictional text.

Methods. To achieve the goal, the authors used theoretical and empirical research methods. Empirical methods included methodology for determining semantic kernels of a text and its probabilistic connection, and methodology for determining the subtext, motives of the author and characters.

Results. Theoretical analysis of the problem led the authors to conclusion that the processes of perceiving and understanding large literary text by philology students are based on two main components: cognitive skills and personal emotional feelings. The process of a literary text perceiving includes such structural elements as the reader's orientation and the type of student's work with a literary text, depends on students' personal professional neoformations (reading competence, speech-cognitive competence), and is also influenced with philology student's psychological type. The results of empirical study conducted by the authors indicate that future teachers of language have following developed reproductive skills with voluminous literary texts: they at a high level reproduce factual information of a text, can accurately convey an emotional load of a literary work, determine its theme, main idea, etc.

Conclusions. The productive types of voluminous literary texts understanding associated with the definition of subtext, motives of the author and characters are mastered by philological students in a rather limited degree and this fact necessitates following studying underlying mechanisms of these processes functioning and developing tools for its targeted progress.

Key words: literary text, perceiving a text, understanding a text, subtext, motive, philology students.

\section{Вступ}

Сучасна психолінгвістика системно досліджує центральну категорію тексту, ознаки текстуальності, проблеми смислового сприйняття вербальної інформації, взаємодії реципієнта й художнього твору, аналізу, інтерпретації та розуміння тексту, утворення проекцій твору в свідомості індивіда тощо (Костюк, 1950; Жинкин, 1982; Выготский, 1982; Black, 1989; Лурия, 1998; Калмикова, Калмиков, 
Лапшина \& Харченко, 2008; Кирсанова, 2009; Матвеева, 2009; Засєкін, 2012; Куранова, 2012; Gibbs, 2013; Kleinschmidt \& Jaeger, 2015; Чепелєва, 2015; Акімова \& Акімова, 2018; Нистратов \& Tарасов, 2018; Tourimpampa, Drigas, Economou \& Roussos, 2018; Beker, Kim, van Boekel, van Broek \& Kendeou, 2019 та ін.). Науковці вивчають типові та особистісні закономірності процесів сприймання та розуміння текстів різних типів, стилів, жанрів адресатами різного віку, статі, професії тощо.

Належне місце в цих наукових розвідках посідає і вивчення особливостей сприймання та розуміння текстів художнього стилю на різних етапах онтогенезу людини. При цьому більшість праць стосуються психології опрацювання літературних творів реципієнтами дошкільного та шкільного віку (Никифорова, 1972; Выготский, 1982; Smith, Macaruso, Shankweiler, \& Crain, 1989; Лурия, 1998; Wauters, Tellings, van Bon \& van Haaften, 2003; Verhoeven \& Perfetti, 2011; Florit, Roch \& Levorato, 2013; Goldfield, Gencarella, \& Fornari, 2016; Валуева, Данилевская, Лаптева \& Ушаков, 2017; Калмикова, Харченко \& Мисан, 2018; Харченко, 2019; Mancuso, Elia, Laudanna \& Vietri, 2019; Nowbakht, 2019 та ін.).

Дещо менше досліджень представлено в проблемному полі розуміння літературних текстів юнаками й дорослими (Кириченко, 2004; Olive, Kellogg \& Piolat, 2008; Литвиненко, 2014; HipfnerBoucher, Lam \& Chen, 2015; Tighe \& Binder, 2015; Новикова, 2016; Tourimpampa, Drigas, Economou \& Roussos, 2018; Beker, Kim, van Boekel, van Broek \& Kendeou, 2019; Jiang \& Kuo, 2019; Metsala, Parrila, Conrad \& Deacon, 2019 та ін.), зокрема студентами-філологами (Кириченко, 2004; Івашкевич, 2018; Ногачевська, 2018; Пустовий, 2019 та ін.). Разом із тим процеси сприймання та розуміння художніх творів становлять важливий компонент професійної діяльності вчителя-філолога, що наразі функціонує зі значними недоліками: фрагментарність сприйняття художнього тексту, ігнорування важливих деталей, символів, підтексту, засобів увиразнення, порушених автором проблем тощо (Кириченко, 2004; Халін, 2006; Івашкевич, 2018; Ногачевська, 2018; Пустовий, 2019 та ін.).

Метою статті є провести теоретичний аналіз проблеми сприймання й розуміння студентами-філологами художнього тексту в психолінгвістичній площині, виявити сформованість їхніх умінь 
i навичок щодо декодування змісту об’ємного прозового твору художньої літератури.

\section{Методи та методики дослідження}

У ході наукового пошуку застосовувалися такі теоретичні методи: аналіз вітчизняних та іноземних наукових джерел із проблем сприймання й усвідомлення художнього тексту, зокрема студентами-філологами; систематизація результатів теоретичного аналізу для отримання цілісного уявлення про ступінь дослідження різних аспектів проблеми в сучасній психолінгвістиці.

До використаних емпіричних методів належали такі: методика визначення смислових ядер тексту та їх імовірнісного зв'язку (Выготский, 1982; Лурия, 1998); методика визначення підтексту художнього твору, мотивів автора й персонажів (Выготский, 1982; Лурия, 1998). Методика визначення смислових ядер та ïx імовірнісного зв'язку передбачала попереднє самостійне ознайомлення респондентів зі значним за обсягом текстом світової літератури - Я. Вишневський «Самотність у Мережі». Під час експериментального дослідження ми поступово ставили завдання на колективне переказування загального змісту твору, виокремлення тематичних блоків у його змісті, формулювання словесних маркерів до смислових ядер, визначення ймовірнісного причиново-наслідкового взаємозв'язок між ними. Після виконання 3 респондентами цієї серії завдань ми проводили якісний аналіз результатів, спрямований на визначення їхньої здатності виділяти смислові ядра в тексті та визначати їх імовірнісний зв'язок.

Застосування методики визначення підтексту та мотивів полягало у письмовому виконанні респондентами чотирьох завдань, що вимагали сформулювати основну думку твору; описати загальний настрій, який викликає прочитання тексту; спробувати визначити внутрішні мотиви автора, що спонукали його до написання твору; визначити підтекст кожної репліки і мотиви персонажів у поданому уривку діалогу 3 тексту твору. Результати виконання завдань піддавалися якісному і кількісному статистичному аналізу, спрямованому на виявлення ступеня розвитку в студентів-філологів умінь визначати підтекст, мотиви автора й персонажів об'ємного твору художньої літератури. 


\section{Результати теоретичного дослідження}

Питання сприймання і розуміння змісту тексту висвітлюються в науковій літературі як на рівні окремих мовних одиниць (фонем, лексем, морфем, синтаксем та ін.), так і загального контексту й дискурсу. Із цього приводу О. Лурія вказував, що процеси декодування та розуміння змісту тексту передбачають сприйняття цілих смислових уривків, яке почасту залежить від розуміння окремого слова, тому логічна послідовність «слово - фраза - текст підтекст» не повинна розумітися як ланцюг реальних послідовних психологічних процесів (Лурия, 1998).

Проблеми розуміння смислу окремих мовних одиниць здебільшого представлено в працях, які стосуються дітей дошкільного та шкільного віку або дорослих 3 особливими потребами. Так, учені досліджують важливість розуміння фонем та загального рівня розвитку усного мовлення для сприймання художніх текстів (Hipfner-Boucher, Lam, \& Chen, 2015 та ін.); вивчають лексичні чинники, що позначаються на розумінні усього тексту (Wauters, Tellings, van Bon \& van Haaften, 2003; Verhoeven \& Perfetti, 2011; Goldfield, Gencarella \& Fornari, 2016; Peters, Grüter \& Borovsky, 2018 та ін.); визначають особливості сприймання та розуміння художнього мовлення дошкільниками й молодшими школярами на рівні фразеологічних та ідіоматичних сполук (Florit, Roch \& Levorato, 2013; Валуева, Данилевская, Лаптева \& Ушаков, 2017; Калмикова, Харченко \& Мисан, 2018; Mancuso, Elia, Laudanna \& Vietri, 2019 та ін.); описують вплив граматичних навичок читачів, зокрема морфологічної обізнаності та орієнтування в синтаксичних конструкціях (Smith, Macaruso, Shankweiler \& Crain, 1989; Tighe \& Binder, 2015; Metsala, Parrila, Conrad \& Deacon, 2019; Jiang \& Kuo, 2019; Mancuso, Elia, Laudanna \& Vietri, 2019 та ін.) тощо.

Так, у роботі L. Verhoeven \& C. Perfetti (2011) описано лексичний та нелексичний аналіз слова як способи усвідомлення змісту прочитаного. Автори зауважили, що процес осягнення змісту слова в читачів дитячого віку проходить у такій послідовності: складні ортографічні словоформи - орфографічні одиниці морфологічний аналіз - морфо-фонологічні одиниці (морфеми, фонеми) - семантична система. L. Wauters, A. Tellings, W. van Bon \& 
A. van Haaften (2003) зазначили, що процес усвідомлення значення слова молодшими школярами може відбуватися перцептивно, лінгвістично чи комбіновано і способи його опанування змінюються 3 віком дитини.

Вивчаючи взаємозв'язок між лексичними навичками, морфологічною обізнаністю та розумінням прочитаного, Ү. Jiang \& L. Kuo (2019) дійшли висновку, що фонологічні та орфографічні ознаки морфологічно складних слів загалом впливають на усвідомлення їх значення студентами коледжу, проте значно більшу дію справляє правильне розуміння значень окремих морфем. J. Metsala, R. Parrila, N. Conrad \& S. Deacon (2019) з'ясували, що лише морфологічна обізнаність уможливлює розуміння прочитаного за межами розбіжностей, які пояснюються читанням окремих слів, i $є$ унікально важливою для розуміння студентами цілого тексту. Проводячи дослідження на дорослих реципієнтах із низьким рівнем грамотності, E. Tighe \& K. Binder (2015) дійшли подібного висновку щодо важливості їхньої морфологічної обізнаності для кращого сприймання та розуміння художніх творів.

Вивчаючи сприймання і розуміння змісту на рівні тексту в єдності його контекстуальних ознак, науковці визначили загальні характеристики цього процесу: сприймання може бути ситуативним (фрагментарним) - залежати від пам'яті та уяви (Olive, Kellogg \& Piolat, 2008; Nowbakht, 2019 та ін.), але може бути і глобальним, свого роду схемою світосприйняття (Жинкин, 1982; Костюк, 1950; Куранова, 2012 та ін.); категорія сприйняття багатомірна і включає в себе емоційну обумовленість, операційні механізми та інші явища, над якими домінує концептуальність (Никифорова, 1972; Калмикова, Калмиков, Лапшина \& Харченко, 2008; Кирсанова, 2009; Матвеева, 2009; Чепелєва, 2015; Beker, Kim, van Boekel, van Broek \& Kendeou, 2019 та ін.); сприймання як когнітивна навичка організації, уточнення та інтерпретації сенсорної інформації насамперед пов'язане 3 когнітивними можливостями пам'яті, уваги тощо, а другою частиною цього процесу виступає вплив знань i особистісних характеристик: переживань, ідеалів, переконань тощо (Новикова, 2016; Валуева, Данилевская, Лаптева \& Ушаков, 2017; Нистратов \& Тарасов, 2018; Tourimpampa, Drigas, Economou \& Roussos, 2018 та ін.). 
Н. Акімова та А. Акімова (2018) зазначили, що процес i результат розуміння тексту залежать як від суб'єктивних, так i від об’єктивних чинників i узагальнили наукові підходи до проблеми в таких напрямах: розуміння тексту як пізнання, осмислення, вирішення задач, інтерпретація, усвідомлення та ін. На цій основі дослідниці вибудували шлях розуміння тексту таким чином: сприймання - інтерпретація - ідентифікація - емоційна ідентифікація й усвідомлення. Узагальнюючи шляхи розуміння тексту, Н. Чепелєва (2015) виділила такі види інтерпретаційних схем: смислові (включають особистісні смисли, мотивоване ставлення до значення); культурні (використовують наявні в культурі зразки); когнітивні (включають концептуальні схеми, знання і уявлення суб'єкта).

Характеризуючи сприймання художнього твору, науковці вказують на його складність та двокомпонентність: механізм творчої та емоційно-вольової активності і механізм образного аналізу художнього тексту (Никифорова, 1972; Кирсанова, 2009; Матвеева, 2009; Gibbs, 2013; Новикова, 2016; Валуева, Данилевская, Лаптева \& Ушаков, 2017; Нистратов \& Тарасов, 2018 та ін.). До основних орієнтирів, які спрямовують творчу активність реципієнта щодо сприймання художнього твору, О. Нікіфорова (Никифорова, 1972) віднесла такі: орієнтування в жанрі та загальному характері твору, місці та часі дії, обсязі твору. У зв'язку з емоційним сприйманням людиною образної системи художнього твору R. Gibbs (2013) обгрунтував категорію «метафорична поведінка людини», зазначаючи, що вона виникає в результаті взаємодії безлічі факторів як частини процесів самоорганізації людини під час сприймання літературного твору.

A. Tourimpampa, A. Drigas, A. Economou \& P. Roussos (2018) вказали, що загалом на сприймання художнього тексту впливають три чинники: особистість адресата, мета і ситуація. Важливість розуміння ситуації мовлення поряд із іншими чинниками обгрунтовано в праці D. Kleinschmidt \& T. Jaeger (2015), де автори зауважили, що система сприймання художнього мовлення має перекодовувати символи на основі а) розпізнавання ситуацій, що виникли раніше; б) узагальнення інших ситуацій, що грунтуються на попередньому досвіді; в) адаптування до нових ситуацій. 
Важливу роль у сприйманні художнього тексту відіграє розуміння його підтексту, мотивів автора і персонажів (Выготский, 1982; Лурия, 1998; Кирсанова, 2009; Матвеева, 2009; Новикова, 2016; Валуева, Данилевская, Лаптева \& Ушаков, 2017; Нистратов \& Тарасов, 2018 та ін.). Із цього приводу О. Лурія зазначав, що «аналіз процесу розуміння змісту висловлення і переходу від системи зовнішніх значень до відбиття внутрішнього підтексту і мотиву залишається центральним і мало розробленим розділом психології пізнавальних процесів» (Лурия, 1998: 316). Е. Black (1989) дійшла висновку, що природу літературного дискурсу слід вивчати через мотиви автора, відношення між історією створення та текстом, а також через діалоги, щоб показати, як на кожному із цих рівнів проявляється вигадана сутність художнього твору та ін.

Зазначені особливості сприймання та розуміння змісту художнього тексту активно вивчаються в сучасній науковій літературі стосовно реципієнтів юнацького та дорослого віку. Так, О. Литвиненко (2014) з'ясувала, що процес сприймання літературного тексту дорослими включає такі структурні елементи, як читацька спрямованість (суб'єктна, акціональна та емоційна) та тип роботи людини 3 літературним текстом (аналітичний, формалізований, інтуїтивний та глибинний). Серед представників різних соціальних та вікових груп дослідниця виокремила психологічні типи читачів літературних текстів: активний; інертний; пасивний; мисленнєвий; дієвий; натуралістичний (високий рівень); натуралістичний (низький рівень).

Аналізуючи сприймання художнього тексту (поетичного твору) студентами-філологами, I. Ногачевська (2018) визначила психологічні особливості його розуміння майбутніми вчителямисловесниками, які вказують на взаємну кореляцію основних його складників (ідея, тема, фактуальна й емоційна інформація) та особистісних професійних новоутворень студентів (читацька компетентність, мовленнєво-мисленнєва компетентність). Крім того, авторка виокремила такі типові труднощі: розуміння імпліцитної інформації, усвідомлення власних переживань, виокремлення ключових слів, художніх деталей, новотворів, недостатня сформованість діалогічної взаємодії з текстом та ін.

Результати досліджень Р. Кириченко (2004) щодо розуміння майбутніми філологами навчальних текстів також свідчать, 
що здебільшого студенти не володіють основними операціями розуміння тексту та прийомами діалогічної взаємодії 3 ними, не мають необхідних комунікативних знань, не вміють грамотно, логічно, ясно висловлювати свої думки та співвідносити власні комунікативні прояви 3 навчальною діяльністю.

Отже, висвітлення проблем сприймання i розуміння змісту тексту в науковій літературі $є$ різноспектним i характеризується певними тенденціями: на рівні розуміння значення окремих фонем, лексем, фразем та ін. здебільшого розглядається для реципієнтів дошкільного та молодшого шкільного віку; на рівні морфологічної та синтаксичної обізнаності - для старших школярів та студентів коледжів чи дорослих 3 особливими потребами; на рівні цілого контексту і дискурсу - для студентів закладів вищої освіти, зокрема майбутніх філологів.

Процеси сприймання та розуміння студентами-філологами художнього тексту великого обсягу грунтуються на двох основних складниках: когнітивних навичках, можливостях пам'яті, уваги тощо та особистісних характеристиках i емоційних переживаннях студента. Процес сприймання літературного тексту включає такі структурні елементи, як читацька спрямованість та тип роботи студента 3 літературним текстом, залежить від ступеня сформованості особистісних професійних новоутворень студентів (читацька компетентність, мовленнєво-мисленнєва компетентність), а також перебуває під впливом психологічного типу, до якого належить студент-філолог: активний; інертний; пасивний; мисленнєвий; дієвий; натуралістичний.

\section{Результати емпіричного дослідження}

Маючи на меті виявити деякі аспекти актуального стану розвитку умінь студентів-філологів сприймати й розуміти текст художніх творів великого обсягу, ми використали методику визначення смислових ядер тексту та їх імовірнісного зв'язку (Выготский, 1982; Лурия, 1998) i методику визначення підтексту й мотивів (Выготский, 1982; Лурия, 1998), спрямовані на діагностування умінь і навичок студентів-філологів декодувати зміст об’ємного твору художньої літератури. Матеріалом для застосування методик було обрано твір Я. Вишневського «Самотність у Мережі». 
Дослідження проводилося на вибірці із 60 студентів філологічного факультету. Умовою проведення експерименту було попереднє ознайомлення респондентів із текстом твору.

Застосування методики виділення окремих смислових ядер та визначення їх імовірнісного зв'язку проводилося в процесі екпериментального дослідження в такій послідовності:

1. Обговорення загального змісту тексту та перебігу подій у ньому за допомогою постановки запитань репродуктивного типу, напр.: «Який час описано в творі?», «Хто виступає головними героями?», «Де відбувалися основні події?», «Що врешті трапилося з героями?» і под.

2. Виокремлення «переламних моментів» у змісті твору, у які змінювався хід подій, стислий переказ змісту виділених тематичних блоків.

3. Колективне формулювання смислових маркерів для виділених ядер: знайомство головних героїв у Мережі листування - зустріч - драма - розставання.

4. Обговорення взаємозв'язку між смисловими ядрами за допомогою запитань на антиципацію, напр.: «Який розвиток подій Ви уявляли, коли вперше прочитали про знайомство головних героїв у Мережі?», «Наскільки Ваші думки були близькі до оригіналу тексту?», «Чи була закладена вже в змісті листування головних героїв драматична розв'язка стосунків?» та ін.

У процесі реалізації всіх етапів методики визначення смислових ядер тексту та їх імовірнісного зв'язку ми переконалися, що абсолютна кількість студентів здатні передати події твору, поділити його на смислові частини та переказати, так же, як i номінувати та визначити послідовність і взаємозв'язок смислових ядер тексту.

Наступним етапом емпіричного дослідження стало виявлення глибини сприймання й розуміння тексту за методикою визначення підтексту та мотивів, для чого ми запропонували респондентам письмові завдання:

1. Сформулюйте основну думку, яку автор хотів донести до читача.

2. За загальним настроєм, що викликає прочитання тексту, спробуйте визначити внутрішні мотиви автора, причини для написання твору. 
Analysis of Problem of Perceiving and Understanding Literary...

3. Обгрунтуйте відсутність у творі імені головної героїні.

4. Визначте підтекст кожної репліки в наступному уривку i мотиви персонажів:

Р.1. ВОНА: Ти думаєш, що слов'янам може стати в пригодi nсихотерапевт? Чи Ти ще далі слов'янин?

Р.2. ВІН: Мабуть, уже ні. Я не п'ю горілки, я пунктуальний, дотримую слова $i$ не організовую повстань. Але психотерапевта я мав навіть у Польщі. Проте це було так давно, щуо його тодi називали психіатром.

P.3. ВОНА: I Тобі допоміг ичей психіатр?

P.4. ВІН: Сам психіатр - ні. Але те, щ̧о я почув у його приймальні, мені дуже допомогло.

P.5. ВОНА: У Тебе був хворий розум чи душа? (Вишневський, 2019)

Перше та друге завдання ми віднесли до частково репродуктивного типу, оскільки в них вимагалося відтворити власні думки та емоції, які відчували студенти під час сприймання тексту, а третє і четверте - до продуктивного, бо для їх виконання вимагалося додаткове осмислення тексту, подій у ньому, обдумування реплік персонажів тощо.

Аналіз студентських відповідей на перше завдання показав деякі розбіжності у визначенні головної думки, які ми за смислом узагальнили в таких твердженнях: «Усім людям в усі часи не вистачає кохання» $(63,3 \%, \mathrm{n}=38)$, «поза Інтернетом самотність переслідує людину» $(25,0 \%, \mathrm{n}=15)$, «Віртуальне кохання не має смислу в реальності» $(11,7 \%, \mathrm{n}=7)$. Кількісні результати виконання першого завдання свідчать, що опитувані осягнули головну думку твору, тому успішно й переважно правильно виконали це завдання. Під час його виконання не виникало додаткових запитань, отже, операція визначення головної думки тексту великого обсягу $\epsilon$ опанованою респондентами на високому рівні.

Друге завдання мало еталонну відповідь, оскільки сам автор зауважував, що йому було сумно після розлучення 3 дружиною i хотілося «виплеснути» самотність і тугу в художньому творі (Вишневський, 2019). Серед студентських відповідей наближеними до еталонної виявилися понад 88,3\% (n = 53), що є задовільним результатом. Під час читання майбутні вчителі осягнули емоційний посил автора i правильно визначили мотиви написання твору, 
хоча формулювання цих мотивів дещо розбігалися: «йому було погано (самотньо) і в тексті він показав безнадію», «текст викликає сум і деякі негативні відчуття, тож, це і було мотивом автора до написання», «він хотів привернути увагу якомога більшої кількості людей до своїх проблем» і под.

Відтак результати виконання другого завдання показали, що емоційне сприймання твору, розуміння емоцій персонажів у ньому та мотивів автора також відбувається в респондентів на достатньому рівні. Однак, вважаємо, що подальшого вивчення потребує емоційність сприймання та розуміння ними творів художньої літератури з меншим емоційним навантаженням.

Аналіз результатів виконання третього завдання засвідчив, що більшість студентів-філологів під час читання тексту не замислювалися над причинами знеособлення головної героїні чи взагалі не помітили відсутності в неї імені, тому запитання виявилося для більшості 3 них несподіваним. Узагальнивши за основним змістом досить різні зразки відповідей, ми отримали такі типові варіанти: «ії практично не існувало в його реальності, тому і імені не потрібно» $(16,7 \%, \mathrm{n}=10)$, «оскільки кохання зрадила жінка, а не Якуб, то він має ім'я, а вона - ні» $(28,3 \%, \mathrm{n}=17)$, «у неї було ім'я: iii звали Наталя (Дженніфер)» $(25,0 \%, \mathrm{n}=15)$, «я не замислювався (замислювалась)» $(30,0 \%, \mathrm{n}=18)$. Ці результати ми інтерпретували як переважну відсутність у респондентів глибокого розуміння підтексту і мотивів автора, оскільки лише 45,0\% $(\mathrm{n}=27)$ iз них надали певне тлумачення авторській задумці, а 55,0\% $(\mathrm{n}=33)-$ узагалі не замислювалися над нею чи відповіли неправильно.

Четверте завдання було найскладнішим і вимагало глибокого занурення в прихований смисл реплік персонажів. Результати його виконання засвідчили практичне незнання студентами значення терміну «підтекст» та невміння визначати його. Не виконали це завдання взагалі $13,3 \%(\mathrm{n}=8)$ опитуваних; виконали помилково або частково правильно $65,0 \%(\mathrm{n}=39)$; виконали правильно лише $21,7 \%$ ( $=13)$. Під час виконання завдання більшість респондентів хотіли отримати додаткові пояснення та допомогу у виконанні.

Помилкові відповіді містили незрозумілі, неправильні тлумачення чи переписування змісту репліки персонажа іншими словами, напр., до Р.1: «вона хоче сказати, що слов'янам не потрібні психотерапевти», «вона хоче дізнатися його справжню 
національність» тощо. Найбільше правильних або близьких до правильної відповідей відзначилося до Р.5: «вона залицяється до нього», «вона показує, що хоче пізнати його ближче» та ін.

Отже, результати виконання четвертого завдання засвідчили, що достатніх навичок розуміння підтексту в студентів-філологів немає, що обумовлює потребу в розробленні спеціальних заходів щодо їх цілеспрямованого навчання визначати підтекст, проникати в задум та мотиви автора у великих за обсягом текстах художньої літератури. Водночас аналіз результатів виконання першого та другого завдань, які мали більш репродуктивний характер, значно вищі і демонструють наявність і сформованість навичок респондентів визначати головну думку твору та його загальне емоційне забарвлення.

\section{Дискусії}

Емпіричні дослідження щодо сприймання i усвідомлення студентами-філологами змісту тексту проводилися в межах наукових пошуків українських учених (Кириченко, 2004; Івашкевич, 2018; Ногачевська, 2018; Пустовий, 2019), у яких автори дійшли аналогічних висновків про недостатню сформованість умінь i навичок майбутніх філологів декодувати зміст тексту та організовувати діалогічну взаємодію із ним. Однак предмет дослідження в роботах цих науковців не передбачав вивчення проблеми розуміння підтексту та мотивів на матеріалі прозового художнього тексту великого обсягу, тому статистичних даних щодо порушеного питання в науковій думці обмаль. Отримані нами результати передбачають подальшу наукову дискусію в проблемному полі сприймання і розуміння філологами підтексту та мотивів на рівні загального контексту та дискурсу великого прозового твору художньої літератури.

\section{Висновки}

Аналіз проблеми сприймання $\mathrm{i}$ розуміння студентамифілологами художніх текстів великих обсягів засвідчив певні недоліки в теоретичному вивченні питання, оскільки в науковій 
теорії майже відсутні праці, у яких комплексно висвітлено особливості декодування ними прозового тексту великого обсягу, зокрема i 3 урахуванням вимог майбутньої професійної діяльності. Вірогідно, що саме цей факт негативно позначається на сформованості відповідних умінь і навичок майбутніх учителів осягати зміст таких творів, причому одним із важливих i найменш досліджених напрямів вирішення цієї проблеми $є$ вивчення глибинних механізмів, спрямованих на усвідомлення підтексту, мотивів автора, персонажів тощо.

Результати теоретичного аналізу продемонстрували, що процеси сприймання та розуміння студентами-філологами художнього тексту великого обсягу грунтуються на двох основних складниках: когнітивних навичках, можливостях пам'яті, уваги тощо та особистісних характеристиках i емоційних переживаннях студента. Процес сприймання літературного тексту включає такі структурні елементи, як читацька спрямованість та тип роботи студента 3 літературним текстом, залежить від ступеня сформованості особистісних професійних новоутворень студентів, а також перебуває під впливом психологічного типу, до якого належить студент-філолог: активний; інертний; пасивний; мисленнєвий; дієвий; натуралістичний.

Результати емпіричного дослідження засвідчили, що в респондентів наявні розвинені навички репродуктивної роботи із текстами великих обсягів: вони на високому рівні відтворюють фактуальну інформацію тексту, можуть визначати емоційне навантаження твору, його тему, головну думку, загалом орієнтуються у виділенні смислових ядер тексту та визначенні їх взаємозв’язку. Поряд із цим продуктивні види осмислення підтексту та мотивів автора і персонажів опановано студентами-філологами на низькому рівні, що обумовлює потребу вивчення глибинних механізмів функціонування цих процесів та розроблення заходів щодо їх цілеспрямованого розвитку.

До перспективних напрямів дослідження проблеми сприймання та розуміння художнього тексту студентами-філологами відносимо такі: вивчення особливостей функціонування творчої уяви респондентів, що активізується перед читанням художнього твору у процесі попереднього ознайомлення 3 ним через систему позатекстових ознак: тема, жанр, обсяг, заголовок, епіграф тощо, 
а також виокремлення чинників, які впливають на іiі розвиток; кореляція процесів інтерпретації, ідентифікації та усвідомлення тексту художнього твору залежно від ступеня обізнаності кожного студента 3 теорією літератури, його індивідуальних розумових, емоційних, сенсорних особливостей; емоційність сприймання та розуміння респондентами творів художньої літератури 3 помірним емоційним навантаженням та ін.

\section{Література}

Акімова, Н., \& Акімова, А. (2018). Розуміння тексту як специфічний вид розуміння. Психолінгвістика. Психолингвистика. Psycholinguistics, 24(2), 2747. https://doi.org/10.31470/2309-1797-2018-24-1-27-46

Валуева, Е.А., Данилевская, Н.М., Лаптева, Е.М., \& Ушаков, Д.В. (2017). Когнитивная сложность художественных текстов для детей: квантитативные методы оценки. Вопросы психолингвистики, 1(31), 42-61.

Вишневський, Я.Л. (2019). Самотність у мережі. О. Кравець (Перекл.). Київ: Рідна Мова.

Выготский, Л.С. (1982). Проблемы общей психологии. Собрание сочинений (Т. 1-6). (Т. 2. С. 3-354). Москва: Педагогика.

Жинкин, Н.И. (1982). Речь как проводник информаџии. Москва: Наука.

Засєкін, С.В. (2012). Психолінгвістичні універсалії перекладу художнього тексту. Луцьк: Волин. нац. ун-т ім. Лесі Українки.

Івашкевич, Е.Е. (2018). Психологічні чинники професійного становлення майбутнього перекладача. Дис. канд. психол. наук. Рівне.

Калмикова, Л.О., Калмиков, Г.В., Лапшина, І.М., \& Харченко, Н.В. (2008). Психологія мовлення і психолінгвістика. Київ: ПДПУ - «Фенікс».

Калмикова, Л., Харченко, Н., \& Мисан, І. (2018). Особливості розуміння дітьми дошкільного віку переносного значення прислів'їв та ідіом. Психолінгвістика.Психолингвистика.Psycholinguistics, 24(1), 149-182. https://doi.org/10.31470/2309-1797-2018-24-1-149-182

Кириченко, Р.В. (2004). Вплив смислової структури тексту на його розуміння студентами. Дис. канд. психол. наук. Київ.

Кирсанова, И.В. (2009). Индивидуальные стратегии понимания текста как реализация механизмов смыслообразования. Вопросы психолингвистики, 9, 257-261.

Костюк, Г.С. (1950). Про психологію розуміння. Наукові записки НДІ психології УРСР (с. 7-57). Київ: Радянська школа.

Куранова, С.І. (2012). Основи психолінгвістики. Київ: ВЦ «Академія».

Литвиненко, О.О. (2014). Індивідуально-психологічні особливості сприймання літературного тексту. Автореф. дис. канд. психол. наук. Київ.

Лурия, А.Р. (1998). Язык и сознание. Ростов-на-Дону: Изд-во «Феникс».

Матвеева, Н.В. (2009). Экспериментальное исследование механизмов формирования содержания и смысла текста в процессе его понимания. Вопросы психолингвистики, 9, 261-266. 
Аналіз проблеми сприймання й розуміння студентами-філологами...

Никифорова О.И. (1972). Психология восприятия художественной литературы. Москва: Книга.

Нистратов, А.А., \& Тарасов, Е.Ф. (2018). Восприятие текста в зависимости от коммуникативной позиции испытуемого. Вопросы психолингвистики, 4(38), 98-112. doi: 10.30982/2077-5911-2018-4-98-111

Новикова, В.П. (2016). Интеллект-карта как эффективный инструмент работы с художественным текстом. Вопросы психолингвистики, 30, 156-164.

Ногачевська, I.О. (2018). Психологічні особливості розуміння майбутніми вчителями-філологами сучасного поетичного тексту. Автореф. дис. канд. психол. наук. Переяслав-Хмельницький.

Пустовий, С.А. (2019). Формування психосемантичного змісту професійної свідомості майбутніх філологів. Дис. канд. психол. наук. Київ.

Халін, В.В. (2006). Розвиток художнього сприймання епічного твору студентами філологічного факультету в процесі вивчення української літератури. Автореф. дис. канд. пед. наук. Київ.

Харченко, Н.В. (2019). Психологія розвитку аудіювання у дітей дошкільного віку. Автореф. дис. д-ра психол. наук. Переяслав-Хмельницький.

Чепелєва, Н.В. (2015). Текст і читач. Житомир: Вид-во ЖДУ ім. І. Франка.

Beker, K., Kim, J., van Boekel, M., van Broek, P., \& Kendeou, P. (2019). Refutation texts enhance spontaneous transfer of knowledge. Contemporary Educational Psychology, 56, 67-78. https://doi.org/10.1016/j.cedpsych.2018.11.004

Black, E. (1989). The Nature of Fictional Discourse: A Case Study. Applied Linguistics, 10(3), 281-293. https://doi.org/10.1093/applin/10.3.281

Florit, E., Roch, M., \& Levorato, M. (2013). The relationship between listening comprehension of text and sentences in preschoolers: Specific or mediated by lower and higher level components? Applied Psycholinguistics, 34(2), 395-415. https://doi.org/10.1017/S0142716411000749

Gibbs, R. (2013). The real complexities of psycholinguistic research on metaphor. Language Sciences, 40, 45-52. https://doi.org/10.1016/j.langsci.2013.03.001

Goldfield, B., Gencarella, C., \& Fornari, K. (2016). Understanding and assessing word comprehension. Applied Psycholinguistics, 37(3), 529-549. https://doi. org/10.1017/S0142716415000107

Hipfner-Boucher, K., Lam, K., \& Chen, X. (2015). The contribution of narrative morphosyntactic quality to reading comprehension in French immersion students. Applied Psycholinguistics, 36(6), 1375-1391. https://doi.org/10.1017/ S0142716414000319

Jiang, Y., \& Kuo, L. (2019). The development of vocabulary and morphological awareness: A longitudinal study with college EFL students. Applied Psycholinguistics, 40(4), 877-903. https://doi.org/10.1017/S014271641900002X

Kleinschmidt, D.F., \& Jaeger, T.F. (2015). Robust speech perception: Recognize the familiar, generalize to the similar, and adapt to the novel. Psychological Review, 122(2), 148-203. https://doi.org/10.1037/a0038695

Mancuso, A., Elia, A., Laudanna, A., \& Vietri, S. (2019). The Role of Syntactic Variability and Literal Interpretation Plausibility in Idiom Comprehension. Journal of Psycholinguistic Research, 48(274), 1-26. https://doi.org/10.1007/ s10936-019-09673-8

Metsala, J., Parrila, R., Conrad, N., \& Deacon, S. (2019). Morphological awareness and reading achievement in university students. Applied Psycholinguistics, 40(3), 743-763. https://doi.org/10.1017/S0142716418000826 
Nowbakht, M.J. (2019). The Role of Working Memory, Language Proficiency, and Learners' Age in Second Language English Learners' Processing and Comprehension of Anaphoric Sentences. Journal of Psycholinguistic Research, 48(2), 353-370. https://doi.org/10.1007/s10936-018-9607-2

Olive, T., Kellogg, R., \& Piolat, A. (2008). Verbal, visual, and spatial working memory demands during text composition. Applied Psycholinguistics, 29(4), 669-687. https://doi.org/10.1017/S0142716408080284

Peters, R., Grüter, T., \& Borovsky, A. (2018). Vocabulary size and native speaker self-identification influence flexibility in linguistic prediction among adult bilinguals. Applied Psycholinguistics, 39(6), 1439-1469. https://doi.org/10.1017/ S0142716418000383

Smith, S., Macaruso, P., Shankweiler, D., \& Crain, S. (1989). Syntactic comprehension in young poor readers. Applied Psycholinguistics, 10(4), 429-454. https://doi. org/10.1017/S0142716400009012

Tighe, E., \& Binder, K. (2015). An investigation of morphological awareness and processing in adults with low literacy. Applied Psycholinguistics, 36(2), 245-273. https://doi.org/10.1017/S0142716413000222

Tourimpampa, A., Drigas, A., Economou, A., \& Roussos, P. (2018). Perception and Text Comprehension. It's a Matter of Perception! International Journal of Emerging Technologies in Learning (iJET), 13(07), 228-242. https://doi. org/10.3991/ijet.v13i07.7909

Verhoeven, L., \& Perfetti, C. (2011). Morphological processing in reading acquisition: A cross-linguistic perspective. Applied Psycholinguistics, 32(3), 457-466. https:// doi.org/10.1017/S0142716411000154

Wauters, L., Tellings, A., van Bon, W., \& van Haaften, A. (2003). Mode of acquisition of word meanings: The viability of a theoretical construct. Applied Psycholinguistics, 24(3), 385-406. https://doi.org/10.1017/S0142716403000201

\section{References}

Akimova, N., \& Akimova, A. (2018). Rozuminnia tekstu yak spetsyfichnyi vyd rozuminnia [Text understanding as a special kind of understanding]. Psikholingvistika - Psycholinguistics, 24(2), 27-47. https://doi.org/10.31470/23091797-2018-24-1-27-46 [in Ukrainian].

Valueva, E.A., Danilevskaya, N.M., Lapteva, E.M., \& Ushakov, D.V. (2017). Kognitivnaya slozhnost hudozhestvennyih tekstov dlya detey: kvantitativnyie metodyi otsenki [Cognitive Complexity of Children Fiction: Quantitative Methods of Evaluation]. Voprosy psiholingvistiki - Journal of Psycholinguistics, 1(31), 42-61 [in Russian].

Vyshnevskyi, Ya.L. (2019). Samotnist u merezhi [Loneliness on the Network]. In O. Kravets (Transl.). Kyiv: Ridna Mova [in Ukrainian].

Vygotskyi, L.S. (1982). Problemi obshchei psykholohyiy [Problems of General Psychology]. Sobranie sochinenij - Collected works (Vols. 1-6). (Vol. 2, pp 3-354). Moscow: Pedahohyka [in Russia].

Zhinkin, N.I. (1982). Rech kak provodnyk informatsyy [Speech as Medium of Information]. Moscow: Nauka [in Russia].

Zasekin, S.V. (2012). Psykholinhvistychni universalii perekladu khudozhnoho tekstu [Psycholinguistic universals of translating fiction texts]. Lutsk: Lesya Ukrainka Volin. Nat. Univer. [in Ukrainian]. 
Ivashkevych, E.E. (2018). Psykholohichni chynnyky profesiinoho stanovlennia maibutnoho perekladacha [Psychological Factors of Professional Formation of Future Translator]. Candidate's thesis. Rivne: RDGU [in Ukrainian].

Kalmykova, L.O., Kalmykov, H.V., Lapshyna, I.M., \& Kharchenko, N.V. (2008). Psykholohiia movlennia $i$ psykholinhvistyka [Psychology of Speech and Psycholinguistics]. Kyiv: PDPU «Feniks» [in Ukrainian].

Kalmykova, L., Kharchenko, N., \& Mysan, I. (2018). Osoblyvosti rozuminnia ditmy doshkilnoho viku perenosnoho znachennia prysliviv ta idiom [Features of understanding children of preschool age portable value of proverbs and idioms]. Psikholingvistika - Psycholinguistics, 24(1), 149-182. https://doi. org/10.31470/2309-1797-2018-24-1-149-182 [in Ukrainian]

Kyrychenko, R.V. (2004). Vplyv smyslovoi struktury tekstu na yoho rozuminnia studentamy [The Influence of Semantic Structure of Text on its Understanding by Students]. Candidate's thesis. Kyiv [in Ukrainian].

Kirsanova, I.V. (2009). Individualnyie strategii ponimaniya teksta kak realizatsiya mehanizmov smyisloobrazovaniya [Individual Text Comprehension Strategies as Implementation of Meaning Producing Mechanisms]. Voprosy psiholingvistiki Journal of Psycholinguistics, 9, 257-261 [in Russian].

Kostiuk, G.S. (1950). Pro psykholohiiu rozuminnia [On Psychology of Understanding]. Naukovi zapysky NDI psykholohii URSR - Scientific notes of the Research Institute of Psychology of the USSR (pp. 7-57). Kyiv: Radianska shk. [in Ukrainian].

Kuranova, S.I. (2012). Osnovy psykholinhvistyky [Fundamentals of Psycholinguistics]. Kyiv: «Akademiia» [in Ukrainian].

Lytvynenko, O.O. (2014) Indyvidualno-psykholohichni osoblyvosti spryimannia literaturnoho tekstu [Individual psychological peculiarities of perception of literary text]. Extended abstract of candidate's thesis. Kyiv [in Ukrainian].

Luryia, A.R. (1998) Yazik i soznanye [Language and Consciousness]. Rostov-na-Donu: «Fenyks» [in Russia].

Matveyeva, N.V. (2009). Eksperimentalnoe issledovanie mehanizmov formirovaniya soderzhaniya i smyisla teksta $\mathrm{v}$ protsesse ego ponimaniya [Experimental Study of Text-Meaning and Text-Content Forming Mechanisms in the Process of Comprehension]. Voprosy psiholingvistiki - Journal of Psycholinguistics, 9, 261266 [in Russian].

Nykyforova, O.Y. (1972). Psykholohyia vospryiatyia khudozhestvennoi lyteraturi [Psychology of Perception of Fiction]. Moscow: Knyha [in Russia].

Nistratov, A.A., \& Tarasov, E.F. (2018). Vospriyatie teksta v zavisimosti ot kommunikativnoy pozitsii ispyituemogo [A Correlation Between Text Perception and Person's Communicative Attitude]. Voprosy psiholingvistiki - Journal of Psycholinguistics, 4(38), 98-112. doi: 10.30982/2077-5911-2018-4-98-111 [in Russian].

Novikova, V.P. (2016). Intellekt-karta kak effektivnyiy instrument rabotyi s hudozhestvennyim tekstom [Mind-Map as an Effective Instrument to Perfect the Study of the Fiction Text]. Voprosy psiholingvistiki - Journal of Psycholinguistics, 30, 156-164 [in Russian].

Nohachevska, I.O. (2018). Psykholohichni osoblyvosti rozuminnia maibutnimy vchyteliamy-filolohamy suchasnoho poetychnoho tekstu [Psychological peculiarities of understanding future teachers-philologists of modern poetic text]. Extended abstract of candidate's thesis. Pereiaslav-Khmelnytskyi [in Ukrainian]. 
Pustovyi, S.A. (2019). Formuvannia psykhosemantychnoho zmistu profesiinoi svidomosti maibutnikh filolohiv [Formation of Psychosemantic Content of Professional Consciousness of Future Philologists]. Candidate's thesis. Kyiv [in Ukrainian].

Khalin, V.V. (2006). Rozvytok khudozhnoho spryimannia epichnoho tvoru studentamy filolohichnoho fakultetu v protsesi vyvchennia ukrainskoi literatury [Development of artistic perception of an epic work by students of the philological faculty in the process of studying Ukrainian literature]. Extended abstract of candidate's thesis. Kyiv [in Ukrainian].

Kharchenko, N.V. (2019). Psykholohiia rozvytku audiiuvannia u ditei doshkilnoho viku [Psychology of the Development of Listening Comprehension in Children of Preschool Age]. Extended abstract of Doctor's thesis. Pereiaslav-Khmelnytskyi [in Ukrainian].

Chepelieva, N.V. (2015). Tekst $i$ chytach [Text and Reader]. Zhytomyr: Ivan Franko ZhDU [in Ukrainian].

Beker, K., Kim, J., van Boekel, M., van Broek, P., \& Kendeou, P. (2019). Refutation texts enhance spontaneous transfer of knowledge. Contemporary Educational Psychology, 56, 67-78. https://doi.org/10.1016/j.cedpsych.2018.11.004

Black, E. (1989). The Nature of Fictional Discourse: A Case Study. Applied Linguistics, 10(3), 281-293. https://doi.org/10.1093/applin/10.3.281

Florit, E., Roch, M., \& Levorato, M. (2013). The relationship between listening comprehension of text and sentences in preschoolers: Specific or mediated by lower and higher level components? Applied Psycholinguistics, 34(2), 395-415. https://doi.org/10.1017/S0142716411000749

Gibbs, R. (2013). The real complexities of psycholinguistic research on metaphor. Language Sciences, 40, 45-52. https://doi.org/10.1016/j.langsci.2013.03.001

Goldfield, B., Gencarella, C., \& Fornari, K. (2016). Understanding and assessing word comprehension. Applied Psycholinguistics, 37(3), 529-549. https://doi. org/10.1017/S0142716415000107

Hipfner-Boucher, K., Lam, K., \& Chen, X. (2015). The contribution of narrative morphosyntactic quality to reading comprehension in French immersion students. Applied Psycholinguistics, 36(6), 1375-1391. https://doi.org/10.1017/ S0142716414000319

Jiang, Y., \& Kuo, L. (2019). The development of vocabulary and morphological awareness: A longitudinal study with college EFL students. Applied Psycholinguistics, 40(4), 877-903. https://doi.org/10.1017/S014271641900002X

Kleinschmidt, D.F., \& Jaeger, T.F. (2015). Robust speech perception: Recognize the familiar, generalize to the similar, and adapt to the novel. Psychological Review, 122(2), 148-203. https://doi.org/10.1037/a0038695

Mancuso, A., Elia, A., Laudanna, A., \& Vietri, S. (2019). The Role of Syntactic Variability and Literal Interpretation Plausibility in Idiom Comprehension. Journal of Psycholinguistic Research, 48(274), 1-26. https://doi.org/10.1007/ s10936-019-09673-8

Metsala, J., Parrila, R., Conrad, N., \& Deacon, S. (2019). Morphological awareness and reading achievement in university students. Applied Psycholinguistics, 40(3), 743-763. https://doi.org/10.1017/S0142716418000826

Nowbakht, M.J. (2019). The Role of Working Memory, Language Proficiency, and Learners' Age in Second Language English Learners' Processing and Comprehension of Anaphoric Sentences. Journal of Psycholinguistic Research, 48(2), 353-370. https://doi.org/10.1007/s10936-018-9607-2 
Аналіз проблеми сприймання й розуміння студентами-філологами...

Olive, T., Kellogg, R., \& Piolat, A. (2008). Verbal, visual, and spatial working memory demands during text composition. Applied Psycholinguistics, 29(4), 669-687. https://doi.org/10.1017/S0142716408080284

Peters, R., Grüter, T., \& Borovsky, A. (2018). Vocabulary size and native speaker self-identification influence flexibility in linguistic prediction among adult bilinguals. Applied Psycholinguistics, 39(6), 1439-1469. https://doi.org/10.1017/ S0142716418000383

Smith, S., Macaruso, P., Shankweiler, D., \& Crain, S. (1989). Syntactic comprehension in young poor readers. Applied Psycholinguistics, 10(4), 429-454. https://doi. org/10.1017/S0142716400009012

Tighe, E., \& Binder, K. (2015). An investigation of morphological awareness and processing in adults with low literacy. Applied Psycholinguistics, 36(2), 245-273. https://doi.org/10.1017/S0142716413000222

Tourimpampa, A., Drigas, A., Economou, A., \& Roussos, P. (2018). Perception and Text Comprehension. It's a Matter of Perception! International Journal of Emerging Technologies in Learning (iJET), 13(07), 228-242. https://doi. org/10.3991/ijet.v13i07.7909

Verhoeven, L., \& Perfetti, C. (2011). Morphological processing in reading acquisition: A cross-linguistic perspective. Applied Psycholinguistics, 32(3), 457-466. https:// doi.org/10.1017/S0142716411000154

Wauters, L., Tellings, A., van Bon, W., \& van Haaften, A. (2003). Mode of acquisition of word meanings: The viability of a theoretical construct. Applied Psycholinguistics, 24(3), 385-406. https://doi.org/10.1017/S0142716403000201

\section{АНОТАЦІЯ}

Вступ. у статmі обгрунтовано потребу проведення докладного психолінгвістичного дослідження проблеми сприймання та розуміння студентами-фрілологами об'ємного художнього твору, окреслено ії актуальність через недостатню кількість психолінгвістичних досліджень, що розкривають глибинні аспекти цих процесів, а також важливість їх есрективного протікання в професійній діяльності студента-філолога. За мету визначено проведення теоретичного аналізу проблеми сприймання й розуміння студентами-фрілологами художнього тексту в науковій літературі та виявлення рівня сформованості умінь і навичок респондентів щодо декодування змісту об'ємного прозового твору художньої літератури.

методи. Для досягнення мети автори використали теоретичні та емпіричні методи дослідження. До емпіричних належали методика визначення смислових ядер тексту та їх імовірнісного зв'язку і методика визначення підтексту художнього твору, мотивів автора та персонажів.

Результати. Теоретичний аналіз проблеми дозволив зробити висновок, що процеси сприймання та розуміння студентами-фрілологами художнього тексту великого обсягу грунтуються на двох основних складниках: когнітивних навичках та особистісних емоційних переживаннях. Сприймання літературного тексту включає такі структурні елементи, як читацька спрямованість та тип роботи студента з літературним текстом, залежить від ступеня 
сформованості особистісних професійних новоутворень студентів (читацька компетентність, мовленнєво-мисленнєва компетентність), а також перебуває під впливом психологічного типу, до якого належить студентфілолог. Результати емпіричного дослідження вказують на те, що в майбутніх учителів-словесників наявні розвинені навички репродуктивної роботи із текстами великих обсягів: вони на високому рівні відтворюють фактуальну інформацію тексту, можуть досить точно передавати емочійне навантаження твору, визначати його тему, головну думку тощо.

Висновки. Продуктивні види осмислення підтексту та мотивів автора i персонажів наразі опановані студентами-філологами в досить обмеженому обсязі, що обумовлює потребу подальщого вивчення глибинних механізмів функціонування цих процесів та розроблення заходів щодо їх цілеспрямованого розвитку.

Ключові слова: художній текст, сприймання тексту, розуміння тексту, підтекст, мотив, студенти-фрілологи.

\section{Хижняк Инна, Ляшов Назар. Анализ проблемы восприятия и понимания студентами-филологами произведений художественной литературы}

\section{АННОТАЦИЯ}

Вступление. В статье обоснована необходимость проведения детального психолингвистического исследования проблемы восприятия и понимания студентами-срилологами объемного художественного произведения, определены ее актуальность, основывающаяся на недостатке психолингвистических исследований, раскрывающих глубинные аспекты этих процессов, а также важности их эфррективного протекания в профрессиональной деятельности студента-филолога. Целью определено проведение теоретического анализа проблемы восприятия и понимания студентами-филологами художественного текста и выявление уровня сформированности умений и навыков будущих учителей языка и литературы по декодированию содержания большого прозачческого произведения художественной литературы.

Методы. Для достижения цели авторы использовали теоретические и эмпирические методы исследования. К эмпирическим относились методика определения смысловых ядер текста и их вероятностной связи и методика определения подтекста художественного произведения, мотивов автора и персонажей.

Результаты. Теоретический анализ проблемы позволил сделать вывод, что процессы восприятия и понимания студентами-филологами художественного текста больщого объема основываются на двух основных составляющих: когнитивных навыках и личностных эмоциональных перениваниях. Восприятие литературного текста включает такие структурные элементы, как читательская направленность и тип работы студента с литературным текстом, зависит от степени сформированности 
Аналіз проблеми сприймання й розуміння студентами-філологами...

личностных профессиональных новообразований студентов (читательская компетентность, речемыслительная компетентность), а также находится под влиянием психологического типа, к которому принадлежит студентфилолог. Результаты эмпирического исследования указывают на то, что у респондентов имеются развитые навыки репродуктивной работы с текстами больших объемов: они на высоком уровне воспроизводят фактуальную информацию текста, могут достаточно точно передавать эмоциональную нагрузку произведения, определять его тему, главную мысль и под.

Выводы. Продуктивные виды осмысления подтекста, мотивов автора и персонажей на данный момент освоены студентами-филологами в достаточно ограниченном объеме, что обуславливает необходимость дальнейшего изучения глубинных механизмов функционирования этих процессов и разработку средств для их целенаправленного развития.

Ключевые слова: художественный текст, восприятие текста, понимание текста, подтекст, мотив, студенты-филологи. 